\title{
Determination of Amino Acids and Nutritional Aspects in Transgenic Soybean Exposed to Glyphosate
}

\author{
André Luiz de Souza Lacerda ${ }^{1,}$, , Salete Aparecida Sagaziol ${ }^{2}$, Daiana Schmidt ${ }^{2}$, \\ Ricardo Antunes Azevedo \\ ${ }^{1}$ Department of Environment, City Hall of Valinhos, Valinhos, Brazil \\ ${ }^{2}$ Department of Genetic, São Paulo of University, Piracicaba, Brazil
}

Email address:

alslacer@yahoo.com.br (A. L. de S. Lacerda)

${ }^{*}$ Corresponding author

\section{To cite this article:}

André Luiz de Souza Lacerda, Salete Aparecida Sagaziol, Daiana Schmidt, Ricardo Antunes Azevedo. Determination of Amino Acids and Nutritional Aspects in Transgenic Soybean Exposed to Glyphosate. American Journal of Plant Biology. Vol. 4, No. 3, 2019 , pp. 40-45. doi: $10.11648 /$ j.ajpb.20190403.14

Received: September 15, 2019; Accepted: September 29, 2019; Published: October 11, 2019

\begin{abstract}
With the increase of glyphosate tolerant transgenic soybean cultivation areas, this substance has become the main herbicide for this crop, its use may interfere with the metabolism and nutritional aspects of transgenic plants. In this scenario, the objective of this work was to verify the oil, protein, phytate and amino acid concentrations in glyphosate tolerant soybean cultivar. For this, a randomized block experiment with 6 treatments and 4 repetitions was performed. The analyzed cultivar was genetically modified soybean BRS Valiosa RR. The treatments consisted of glyphosate applied once, that is, respectively in the doses: 1,5 and $2,0 \mathrm{~L} \mathrm{ha}^{-1}$ of the commercial product, glyphosate applied sequentially in the doses: $1,5 / 1,5 ; 2.0 / 1.5$ and $2.0 /$ $1.5 / 1.5 \mathrm{~L} \mathrm{ha}^{-1}$ of commercial products, with intervals of 15 to 20 days between applications and control (clean) weeded (without glyphosate application)). Grains were harvested, macerated and $200 \mathrm{mg}$ of each sample was used for extraction of soluble amino acids. After extraction, triplicate aliquots were analyzed to determine total soluble amino acids. For quantitative determination of free amino acids, reverse phase HPLC was used after derivatization with o-ophydialdehyde (OPA) on a Spherisorb ODS-2 (C18) column. OPA derivatives were detected by fluorescence and protein contents were determined by the Kjeldhal and Soxhlet method. The data obtained were submitted to analysis of variance and $\mathrm{F}$ test of the statistical program ASSISTAT version 7.7 beta. Significant analyzes were performed by comparing means by Tukey test at $5 \%$ probability. In conclusion, the data indicate that although the transgenic event affects some routes, amino acid synthesis was not affected nor in nutritional terms at the glyphosate doses studied.
\end{abstract}

Keywords: Soybean, Phytate, Amino Acids, Transgenics, Glyphosate

\section{Introduction}

Glyphosate is a non-selective product that controls large numbers of narrow broadleaved plants by inhibiting EPSP synthetase, an enzyme that participates in the metabolic pathway of aromatic amino acid biosynthesis (tryptophan, tyrosine and lysine), which are essential for growth of the plant [16].

Companies have developed genetically modified soybean cultivars, where the gene (CP4) that encodes the enzyme EPSPs [5-enolpyruvate-shikimate-3-phosphate synthase] inhibits the action of glyphosate. Thus, it is possible that glyphosate tolerant soybeans develop even after application of the glyphosate herbicide.

To understand what has been accomplished, it is necessary to comment on the mode of action of glyphosate. Glyphosate, active ingredient of Roundup ${ }^{\circledR}$ (N-phosphonomethylglycine) herbicide, binds and blocks the activity of the enzyme EPSP (5-enolpyruvylshikimate-3-phosphate) synthase, which participates in the aromatic amino acid biosynthesis in plants. In the absence of glyphosate, the enzyme EPSPS acts by catalyzing the reaction of S3P (or shikimate-3-phosphate) and PEP (phosphoenolpyruvate), giving rise to the production of EPSP (5- 
enolpyruvylshikimate-3-phosphate), which are the substances responsible for the synthesis of aromatic amino acids. Thus, the presence of glyphosate in the plant, restricting the manufacture of aromatic amino acids, makes it impossible to synthesize various proteins, causing the plant to paralyze growth of both the root system and the shoot.

Asparagine (symbol Asn or $\mathrm{N}$ ), is an $\alpha$-amino acid that is used in the biosynthesis of proteins. It contains an $\alpha$-amino group (which is in the protonated $-\mathrm{NH}^{+3}$ form under biological conditions), an $\alpha$-carboxylic acid group (which is in the deprotonated $-\mathrm{COO}^{-}$form under biological conditions), and a side chain carboxamide, classifying it as a polar (at physiological $\mathrm{pH}$ ), aliphatic amino acid. It is nonessential in humans, meaning the body can synthesize it. It is encoded by the codons AAU and AAC [20, 22].

Glutamine is one of the amino acids encoded by the genetic code and is therefore one of the protein components of living things. Glutamine is the free amino acid and is most abundant in muscle tissue. In addition to acting as a nutrient (energy) for immune cells, glutamine has an important anabolic function promoting muscle growth. This effect may be associated with its ability to capture water into the intracellular environment, which thus stimulates protein synthesis. Glutamine is a nonessential amino acid, synthesized from body needs and is the most abundant form of amino acid found in the body. Its synthesis is made from glutamic acid (glutamine is glutamic acid amide), valine and isoleucine $[5,13]$.

Tyrosine (symbol Tyr or Y) or 4-hydroxyphenylalanine is one of the 20 standard amino acids that are used by cells to synthesize proteins. It is a non-essential amino acid with a polar side group. The word "tyrosine" is from the Greek tyrós, meaning cheese, as it was first discovered in 1846 by German chemist Justus von Liebig in the protein casein from cheese. It is called tyrosyl when referred to as a functional group or side chain. While tyrosine is generally classified as a hydrophobic amino acid, it is more hydrophilic than phenylalanine. It is encoded by the codons UAC and UAU in messenger RNA [1, 9, 20, 24].

Methionine (symbol Met or M) is an essential amino acid in humans. As the substrate for other amino acids such as cysteine and taurine, versatile compounds such as SAM-e, and the important antioxidant glutathione, methionine plays a critical role in the metabolism and health of many species, including humans. It is encoded by the codon AUG. Methionine is also an important part of angiogenesis, the growth of new blood vessels. Supplementation may benefit those suffering from copper poisoning. Overconsumption of methionine, the methyl group donor in DNA methylation, is related to cancer growth in a number of studies $[6-8,12,21$, 22].

Valine (symbol Val or V) is an $\alpha$-amino acid that is used in the biosynthesis of proteins. It contains an $\alpha$-amino group (which is in the protonated $-\mathrm{NH}^{+3}$ form under biological conditions), an $\alpha$-carboxylic acid group (which is in the deprotonated $-\mathrm{COO}^{-}$form under biological conditions), and a side chain isopropyl group, making it a non-polar aliphatic amino acid. It is essential in humans, meaning the body cannot synthesize it: it must be obtained from the diet. Human dietary sources are foods that contain protein, such as meats, dairy products, soybean products, beans and legumes. It is encoded by all codons starting with GU (GUU, GUC, GUA, and GUG) [22].

Phenylalanine is one of the essential amino acids for humans, meaning it cannot be synthesized by the human body and must be purchased through diet, as it is about $3.9 \%$ of our body's proteins. Among the amino acid classification, phenylalanine is considered apolar due to the phenyl (aromatic ring) residue that is responsible for the high absorption of UV radiation used in protein quantification. Like almost all amino acids, it has optical activity in its Calfa (carbon 2) having isomers L (levogyrous) and D (dextrogyrous), according to the polarized light deviation. The "L" isomer acts as a protein builder, while the "D" acts as an analgesic. It is noteworthy that the 20 essential amino acids are "L" type. "D" type amino acids can be found in bacteria or originate by inversion of existing "L" types by enzymatic action [23].

Isoleucine (symbol Ile or I) is an $\alpha$-amino acid that is used in the biosynthesis of proteins. It contains an $\alpha$-amino group (which is in the protonated $-\mathrm{NH}^{+3}$ form under biological conditions), an $\alpha$-carboxylic acid group (which is in the deprotonated $-\mathrm{COO}^{-}$form under biological conditions), and a hydrocarbon side chain with a branch (a central carbon atom bound to three other carbon atoms). It is classified as a non-polar, uncharged (at physiological $\mathrm{pH}$ ), branched-chain, aliphatic amino acid. It is essential in humans, meaning the body cannot synthesize it, and must be ingested in our diet. Isoleucine is synthesized from pyruvate employing leucine biosynthetic enzymes in other organisms such as bacteria. It is encoded by the codons AUU, AUC and AUA [17, 22].

Leucina is one of the amino acids encoded by the genetic code and is therefore one of the protein components of living things. Leucine is one of the 20 amino acids that cells in the human body use to synthesize proteins, but it does not produce them. It plays important roles in increasing protein and acts as an energy source during exercise, increasing endurance and reducing fatigue. It is an integral part of the branched chain, together with isoleucine and valine, and is abundantly found in meat and legumes (soybeans and beans), with an average concentration of $1 \mathrm{~g}$ per $100 \mathrm{~g}$ and $3 \mathrm{~g}$ per $100 \mathrm{~g}$, respectively $[14,5]$.

Lysine is a basic polar amino acid encoded by codons AAA and AAG. Highly soluble in water, it was discovered in 1889 by Edmund Drechsel, who first isolated it from Lysine casein [17]. Its structure was elucidated three years later. In humans, the amino acid lysine is exclusively ketogenic. The amino acid lysine began to be added to slaughter animal feed in the second half of the last century. For some animals, such as pigs, it is a limiting amino acid. Lysine supplementation provides the use of cheaper feed, but maintains good protein and growth rates for animals. Annual amino acid production is estimated to exceed 600.000 tonnes[19, 25, 27].

As for phytic acid (myo-inositol hexachisphosphate), 
whose main form of phosphorus storage in grains is 50 to $80 \%$ of total $\mathrm{P}$, commonly constituting about 1.0 to $2.5 \%$ of its dry mass, this substance affects the nutritional value of grains, especially legumes, as it may decrease the bioavailability of minerals and proteins in humans and monogastric animals. On the other hand, it can also have beneficial effects on human health, such as lowering blood cholesterol and triglyceride levels and acting as an antioxidant and anticarcinogen. Due to both positive and negative aspects, the interest in manipulating phytate contents in cereal and pulses has increased. However, it is necessary to better understand the biosynthetic pathway of phytate and the mechanisms that regulate it. One of the priority studies are those relating the levels of phytate and protein in grains, as they are correlated. Phytate is deposited in protein bodies and legumes, it is dispersed in the protein matrix, so it is possible that the accumulation of certain reserve proteins influence phytate synthesis. An experimental model system, in this case the in vitro culture of fruit explants, allows to manipulate the phytate and protein synthesis via changes in the composition of the culture medium, and to analyze the proteins expressed under contrasting phytate synthesis situations $[17,18]$.

\section{Material and Methods}

Field experiment: This experiment was conducted in a randomized block design with nine treatments and four replications. The cultivar analyzed was genetically modified soybean BRS Valiosa RR. Sowing was carried out in October in the agricultural year $2006 / 2007$, with density of 14 to 16 linear plants per meter and spacing of $0.5 \mathrm{~m}$ between rows. The experimental plots consisted of six $5 \mathrm{~m}$ long lines with four replications. It was considered as useful area, the four central lines with $4 \mathrm{~m}$ in length, disregarding $0.5 \mathrm{~m}$ from the ends of each plot.

Treatments: consisted of glyphosate applied only once T1 and $\mathrm{T} 2$, respectively at doses: 1.5 and $2.0 \mathrm{~L} \mathrm{ha}^{-1}$ p.c., glyphosate sequentially applied $\mathrm{T} 3, \mathrm{~T} 4$ and $\mathrm{T} 5$, respectively at doses: $1.5 / 1.5 ; 2.0 / 1.5$ and $2.0 / 1.5 / 1.5 \mathrm{~L} \mathrm{ha}^{-1}$ of p.c, with intervals of 15 to 20 days between applications and T6 clean weeded control (without glyphosate application).

Glyphosate application: The commercial product used was Roundup Ready ${ }^{\circledR}$ in the formulation of $480 \mathrm{~g} \mathrm{~L}^{-1}$ acid equivalent made between 15 and 20 days after emergence of soybean seedlings, from physiological stage V2, when the edges leaves of the second trifolium no longer touch, according to the classification [11]. Applications have been always done in the morning, without wind to avoid drift, with the aid of a constant pressure $\left(\mathrm{CO}_{2}\right)$ costal sprayer, adjusted to syrup volume of $200 \mathrm{~L} \mathrm{ha}^{-1}$ and with fan nozzles $\left(110^{\circ}\right.$ $\mathrm{SF}-02$ ) following the manufacturers recommendations.

Determination of oil and protein: The protein content in $1.0 \mathrm{~g}$ and $0.1 \mathrm{~g}$ oil in soybeans were determined by the Kjeldhal method, using copper sulfate and the Soxhlet method as catalyst, respectively, hexane as a solvent [6].

Phytate determination: $25 \mathrm{~g}$ aliquots were taken from the triplicate soybean sample in the laboratory, which were previously homogenized, crushed and kept in a freezer at a temperature of around $-18^{\circ} \mathrm{C}$ until the time of analysis. The method used was suggested by [17]. Extraction consisted of the addition of $20 \mathrm{~mL} 0.5 \mathrm{~m} \mathrm{Mol}^{-1} \mathrm{HCl}$ to $500 \mathrm{mg}$ of sample. All inositol phosphates in the extract were retained in previously prepared Dowex AG 1-X8 ion exchange resin (400 to 800 mesh). The method was based on the dark blue coloration of the ferro-sulfosalisylic acid compound. In the presence of phytate, the iron complex was precipitated, reducing the intensity of the blue color. The reading was performed in a spectrophotometer at a wavelength of $500 \mathrm{~nm}$.

Separation and analysis of amino acid composition and quantification of seed soluble lysine by HPLC: High performance Liquid Chromatography (HPLC) was employed for the separation and quantitative determination of free amino acids using a Spherisorb ODS-2 reverse phase column (C18) after derivatization with o-ophydialdehyde (OPA) [10]. OPA derivatives were detected by fluorescence, for which 1 $\mathrm{g}$ of flour obtained from the grinding of mature seeds in 10 $\mathrm{ml}$ of MCW (methanol, chloroform and water in the ratio 12: 5: 3) was used. The mixture was left overnight at $4^{\circ} \mathrm{C}$. The supernatant was centrifuged at $6000 \mathrm{rpm}$ for $20 \mathrm{~min}$, then 1 $\mathrm{mL}$ chloroform and $1.5 \mathrm{~mL}$ water were added to each $4 \mathrm{~mL}$ $\mathrm{MCW}$. It was centrifuged again by carefully removing the formed aqueous phase and then lyophilized. The pellet was resuspended in $300 \mathrm{~mL}$ of water and the free amino acid solution frozen at $-20^{\circ} \mathrm{C}$. After thawing, the samples were filtered on a $0.22 \mu$ pore PVDF Millipore filter to remove fractions of reserve proteins, albumin and globulin, which are water soluble and then analyzed by HPLC. OPA derivatives were detected by fluorescence or UV absorption. To a $20 \mathrm{~mL}$ aliquot (standard or sample) was added $60 \mathrm{~mL}$ of the OPA reagent. OPA reagent was prepared by dissolving $50 \mathrm{mg}$ of OPA in $1 \mathrm{~mL}$ of methanol and mixing $6.5 \mathrm{~mL}$ of borate $\mathrm{NaOH}$ buffer $\left(2.4 \% \mathrm{w} \mathrm{v}^{-1}\right.$ boric acid in $\mathrm{H}_{2} \mathrm{O}$; $\mathrm{pH}$ adjusted with $2 \mathrm{M} \mathrm{NaOH}$ ). On the day of the analyzes, $5 \mathrm{~mL}$ of 2 mercaptoethanol was added to $625 \mathrm{~mL}$ of OPA. After exactly 2 minutes, $10 \mathrm{~mL}$ corresponding to each genotype or standard was injected into the HPLC, starting the elution of the mixture on a linear gradient $(20-100 \% \mathrm{~B}$ [methanol $65 \%])$ in buffer $\mathrm{A}\left(50 \mathrm{mM} \mathrm{Na}\right.$ Oac, $50 \mathrm{mM} \mathrm{Na} \mathrm{HPO}_{4}$, tetrahydrafuran, methanol, $\mathrm{pH} 7.25$ ). The flow rate was 0.8 $\mathrm{mL}$ min for $50 \mathrm{~min}$. The gradient has been programmed to linearly increase the ratio of "B" to "A". OPA amino acid derivatives were detected by a fluorescence monitor, $265 \mathrm{~nm}$ excitation and $480 \mathrm{~nm}$ emission. Amino acid concentrations in the samples were determined by the area of the integrated peaks, compared to the peaks of a standard at $250 \mathrm{nmol} \mathrm{mL}^{-1}$. For quantification of lysine specifically, the gradient was repeated, but at a $75-100 \%$ gradient, to allow the appearance of the lysine peak prior to amino acid degradation. Results were expressed as a percentage of moles of amino acids recovered in relation to total amino acids (mol\%).

Total free soluble amino acid (ALT) dosage: After extraction of amino acids, an aliquot of this solution was analyzed to verify total soluble amino acids. A calibration 
curve was constructed using a leucine standard at concentrations of 40, 80, 120, 160 and $200 \mathrm{nmol} \mathrm{mL}^{-1}$. A 100 $\mathrm{mL}$ fraction of the amino acid solution was placed in a test tube by adding $900 \mathrm{~mL}$ of water. For both unknown sample and standard curve analysis, $0.5 \mathrm{~mL}$ of sodium citrate buffer (0.2 M, pH 5.0), $0.2 \mathrm{~mL}$ of ninhhydrin reagent $(5 \%$ in methylglycol) and $1 \mathrm{~mL} \mathrm{KCN} \mathrm{(2 \%} 0.01 \mathrm{M}$ solution in methyl glycol). The test tube was covered with glass balls to prevent evaporation and placed in a water bath at $100^{\circ} \mathrm{C}$ for $20 \mathrm{~min}$. It was allowed to reach room temperature and was completed with $60 \%$ ethanol. Spectrophotometer reading of standards and samples against white was taken at $570 \mathrm{~nm}$.

\section{Results and Discussion}

The results of proteins, lipids, phytate and amino acids are shown in Tables 1 and 2. Table 1 shows that there was no interference in oil and protein production in transgenic soybean due to glyphosate spraying on the crop, but there was an effect phytate production, which should be carefully analyzed, as it is a very important antinutritional factor.

It can be noted that when the application of the product was sequential there was a tendency to decrease phytate, as well as when the applied dosage was lower. But further work must be done to clarify the reason for such behavior, and whether this fact repeats itself in other experiments. The decrease in phytate production may be an incentive for a higher consumption of soybeans within human food.

According the interaction of calcium, phytate and soybean protein seems to be affected by the $\mathrm{pH}$ of the medium and the concentration of the three components. At low $\mathrm{pH}(<4)$, phytate associates with soybean protein to form insoluble complexes in which calcium participation will depend on its concentration. When calcium is in excess, it can displace the phytate from the phytate-protein complex and make it soluble. With high $\mathrm{pH}(>6.5)$ and high calcium concentration, phosphorus precipitates and protein remains soluble as a result of the formation of insoluble calciumphytate complexes. Therefore the $\mathrm{pH}$ may be another factor that explains the lower phytate production due to the ideal $\mathrm{pH}$ in the herbicide syrup used to be acidic [14].

They report that transgenic (T) and non-transgenic (NT) soybean seeds have different concentrations of $\mathrm{Co}, \mathrm{Cu}, \mathrm{Fe}$ and Sr. Bioaccessible fractions of elements such as $\mathrm{Cu}, \mathrm{Fe}$, $\mathrm{Mn}, \mathrm{Zn}$ and $\mathrm{S}$ are higher in soybean seeds transgenic [20].

In Table 2, mean total amino acid values in genetically modified soybean seeds are tolerated and exposed to glyphosate as glyphosate applications, and it was verified that there was no significant difference at the Tukey test level of $5 \%$ without total amino acid levels $\left(\mathrm{nMol} \mathrm{ml} \mathrm{m}^{-1}\right.$ ) for glyphosate doses studied in relation to the control as glyphosate herbicide applications that do not influence the metabolism of soybean plants after total amino acid levels.

Evaluated the activity of some key enzymes involved in combating reactive oxygen species (ROS) as well as differential protein species in the leaves of both soybean genotypes, transgenic (T) and non-transgenic (NT). The results revealed that all the evaluated enzymes presented higher activity in T soybean leaves when compared to NT. Higher concentrations of hydrogen peroxide and malondialdehyde were also observed, clearly indicating an oxidative stress condition established in the transgenic genotype. In addition, 47 proteins were differentially abundant when comparing the leaves of both plants, 26 species were accurately identified, including proteins involved in genetic modification $\left(\mathrm{CP} 4 \mathrm{EPSP}_{\mathrm{S}}\right)$ [2].

The differential evaluation of enzymes and proteins expressed in $\mathrm{T}$ and NT soybean seeds. Analysis of malondialdehyde, ascorbate peroxidase (EC 1.11.1.11), glutathione reductase (EC 1.6.4.2) and catalase (EC 1.11.1.6) revealed higher levels in transgenic seeds $(29.8 ; 30.6 ; 71.4$ and $35.3 \%$, respectively). Protein separation in soybean seeds was performed by two-dimensional polyacrylamide gel electrophoresis and 192 proteins were obtained by laser matrix desorption / ionization (MALDI) in flight time quadrupole (MSQ) analyzed and electrospray ionization (ESI). In addition, CP4 EPSPS enzyme, involved in genetic modification, was identified by enzymatic digestions using trypsin or chymotrypsin and ESI-QTOF MS / MS. Among the identified proteins, cytosolic glutamine synthetase, glycinin subunit G1 and glycine-rich RNA-binding were differentially expressed after analysis using the twodimensional electrophoresis technique and the application of a regulatory factor of 1.5 or greater [3].

The results obtained in the above study indicated that the genetic modification itself could be a stress factor, causing changes in the activity of some enzymes. Changes in soybean seed proteome were corroborated with the production of MDA, which is an indicator of lipid peroxidation and oxidative stress and was higher in soybean seeds. In addition, higher enzymatic activities were observed for APX, GR and CAT in transgenic seeds. This set of results suggests a higher stress level in soybean $\mathrm{T}$ seeds, even when no herbicides were used, since the herbicide resistance gene was inserted into the seed DNA. This fact explains some results previously reported in the literature, stating that transgenic seeds have a greater ability to transport metals from the soil and have greater bioavailability of metals in seeds when compared to non-transgenic soybeans.

In addition, the enzyme involved in genetic modification $\left(\mathrm{CP} 4 \mathrm{EPSP}_{\mathrm{S}}\right)$ was also easily identified by ESI-QTOF MS / MS using trypsin as a cleavage enzyme. Among the 192 proteins identified, four of them were differentially expressed by 2-D DIGE analysis with a regulatory factor of 0.5 or higher. Given the correlation between differentially expressed proteins and the enzymatic activities found, it is not difficult to rationalize that genetic modification induces a condition of oxidative stress in seeds. Tables 3 and 4 show the average values of free amino acids (asparagine, glutamine, tyrosine, methionine, valine, phenylalanine, isoleucine, leucine and lysine) in glyphosate tolerant soybean seeds after exposure to glyphosate applications and none. The treatment significantly influenced the average values of free amino acids and the correlation coefficients between the variables lipids (L), 
proteins $(\mathrm{P})$, phytate $(\mathrm{F})$ and amino acids $(\mathrm{A})$.

Data indicated that although the transgenic event affects some routes, amino acid synthesis was not affected. From the results obtained, the studied organism apparently maintained a similar balance to conventional soybean, so that the genetic modification did not produce significant alterations to maintain its metabolism. This fact is moving researchers working with genetically modified organisms to better understand the specific aspects of genetically modified plant metabolism and to identify key proteins that may eventually be subject to genetic modification so that soybeans can have higher tolerances to the glyphosate herbicide.

Others researchers concluded that isolated or sequential applications of glyphosate did not affect the growth and yield of GM cultivar BRS Valiosa RR soybean, as well as the oil content and protein of GM cultivar were not altered by glyphosate, regardless of its time and dose application [12].

Table 1. Average values of oil, protein and phytate content in glyphosate tolerant genetically modified soybean seeds exposed to glyphosate applications, Esalq / USP, 2007.

\begin{tabular}{|c|c|c|c|c|}
\hline Treatments & Dose (g.i.a ha $\left.{ }^{-1}\right)$ & Oil (\%) & Protein (\%) & Phytate $\left(\mathrm{mg} \mathrm{L}^{-1}\right)$ \\
\hline T1 - Glyphosate & 720 & $18.4 \mathrm{a}$ & $39.3 \mathrm{a}$ & $157.17 \mathrm{bc}$ \\
\hline T2 - Glyphosate & 960 & $18.9 \mathrm{a}$ & $37.1 \mathrm{a}$ & $172.72 \mathrm{ab}$ \\
\hline T3 - Glyphosate / glyphosate & $720 / 720$ & $18.5 \mathrm{a}$ & $39.1 \mathrm{a}$ & $181.84 \mathrm{a}$ \\
\hline T4 - Glyphosate / glyphosate & $960 / 720$ & $18.4 \mathrm{a}$ & $38.1 \mathrm{a}$ & $162.45 \mathrm{ab}$ \\
\hline T5 - Glyphosate/glyphosate/glyphosate & $960 / 720 / 720$ & $18.6 \mathrm{a}$ & $38.7 \mathrm{a}$ & $160.42 \mathrm{abc}$ \\
\hline T6 - Control & --- & $18.8 \mathrm{a}$ & $38.6 \mathrm{a}$ & $174.75 \mathrm{ab}$ \\
\hline $\mathrm{CV}(\%)$ & & 2.0 & 2.5 & 6.0 \\
\hline
\end{tabular}

Means followed by the same letter in the column do not differ statistically from each other by the Tukey test at $5 \%$ probability.

Table 2. Average values of total amino acids in glyphosate tolerant genetically modified soybean seeds exposed to glyphosate applications, Esalq / USP, 2007.

\begin{tabular}{lll}
\hline Treatments & Dose $\left(\mathbf{g . i . a ~} \mathbf{h a}^{-\mathbf{1}}\right)$ & ${\text { Amino acids }\left(\mathbf{n M o l ~} \mathbf{~ m l}^{-\mathbf{1}}\right)}$ \\
\hline T1 - Glyphosate & 720 & $159.73 \mathrm{a}$ \\
T2 - Glyphosate & 960 & $136.05 \mathrm{a}$ \\
T3 - Glyphosate/glyphosate & $720 / 720$ & $175.81 \mathrm{a}$ \\
T4 - Glyphosate/glyphosate & $960 / 720$ & $147.42 \mathrm{a}$ \\
T5 - Glyphosate/glyphosate/glyphosate & $960 / 720 / 720$ & $127.43 \mathrm{a}$ \\
T6 - Control & --- & $136.99 \mathrm{a}$ \\
DMS & & 51.87 \\
CV $(\%)$ & & 26.6 \\
\hline
\end{tabular}

Means followed by the same letter in the column do not differ statistically from each other by the Tukey test at $5 \%$ probability.

Table 3. Mean values of free amino acids (asparagine, glutamine, tyrosine, methionine, valine, phenylalanine, isoleucine, leucine and lysine) in glyphosate tolerant genetically modified soybean seeds exposed to glyphosate applications, Esalq / USP, 2007.

\begin{tabular}{|c|c|c|c|c|c|c|c|c|c|c|}
\hline Treatments & $\begin{array}{l}\text { Doses } \\
\left(\text { g.i.a ha }{ }^{-1}\right)\end{array}$ & Asp & Glu & Tyr & Met & Val & Phe & Ile & Leu & Lys \\
\hline T1 - Glyphosate & 720 & $166.4 \mathrm{a}$ & $334.3 \mathrm{a}$ & $163.6 \mathrm{a}$ & $127.9 \mathrm{a}$ & $146.0 \mathrm{a}$ & $76.1 \mathrm{a}$ & $83.1 \mathrm{a}$ & $78.4 \mathrm{a}$ & 0 \\
\hline T2 - Glyphosate & 960 & $140.5 \mathrm{a}$ & $346.6 \mathrm{a}$ & $134.3 \mathrm{a}$ & $107.6 \mathrm{a}$ & $129.7 \mathrm{a}$ & $49.6 \mathrm{a}$ & $54.9 \mathrm{a}$ & $53.7 \mathrm{a}$ & 0 \\
\hline T3 - Glyphosate/glyphosate & $720 / 720$ & $151.0 \mathrm{a}$ & $326.3 \mathrm{a}$ & $129.0 \mathrm{a}$ & $79.6 \mathrm{a}$ & $137.6 \mathrm{a}$ & $49.0 \mathrm{a}$ & $54.0 \mathrm{a}$ & $55.8 \mathrm{a}$ & 0 \\
\hline T4 - Glyphosate/glyphosate & $960 / 720$ & $137.5 \mathrm{a}$ & $338.6 \mathrm{a}$ & $130.7 \mathrm{a}$ & $79.8 \mathrm{a}$ & $153.5 \mathrm{a}$ & $45.9 \mathrm{a}$ & $52.4 \mathrm{a}$ & $52.2 \mathrm{a}$ & 0 \\
\hline T5- Glyphosate/glyphosate/glyphosate & $960 / 720 / 720$ & $145.7 \mathrm{a}$ & $339.9 \mathrm{a}$ & $127.2 \mathrm{a}$ & $118.3 \mathrm{a}$ & $141.7 \mathrm{a}$ & $49.4 \mathrm{a}$ & $53.1 \mathrm{a}$ & $53.6 \mathrm{a}$ & 0 \\
\hline T6 - Control & --- & $131.1 \mathrm{a}$ & $348.6 \mathrm{a}$ & $132.8 \mathrm{a}$ & $111.5 \mathrm{a}$ & $117.8 \mathrm{a}$ & $50.3 \mathrm{a}$ & $52.8 \mathrm{a}$ & $51.7 \mathrm{a}$ & 0 \\
\hline $\mathrm{CV}(\%)$ & & 30.9 & 34.6 & 31.6 & 44.0 & 31.0 & 32.7 & 31.4 & 31.1 & --- \\
\hline
\end{tabular}

Means followed by the same letter in the column do not differ statistically from each other by the Tukey test at $5 \%$ probability.

Table 4. Correlation coefficient between the variables lipid (L), protein (P), phytate $(F)$ and amino acids (A), Esalq / USP, 2007.

\begin{tabular}{|c|c|c|c|c|c|c|}
\hline \multirow{2}{*}{ Variables } & \multicolumn{6}{|c|}{ Correlation Coefficient (r) } \\
\hline & T1 & T2 & T3 & T4 & T5 & T6 \\
\hline $\mathrm{L} \times \mathrm{P}$ & $-0.45 \mathrm{~ns}$ & $-0.31 \mathrm{~ns}$ & $-0.93 \mathrm{~ns}$ & $0.14 \mathrm{~ns}$ & $-0.25 \mathrm{~ns}$ & $-0.67 \mathrm{~ns}$ \\
\hline $\mathrm{L} \times \mathrm{F}$ & $0.23 \mathrm{~ns}$ & $0.62 \mathrm{~ns}$ & $0.41 \mathrm{~ns}$ & $-0.72 \mathrm{~ns}$ & $-0.11 \mathrm{~ns}$ & $-0.20 \mathrm{~ns}$ \\
\hline $\mathrm{L} \times \mathrm{A}$ & $0.92 \mathrm{~ns}$ & $0.21 \mathrm{~ns}$ & $0.88 \mathrm{~ns}$ & $0.54 \mathrm{~ns}$ & $0.90 \mathrm{~ns}$ & $0.02 \mathrm{~ns}$ \\
\hline $\mathrm{P} \times \mathrm{F}$ & $0.14 \mathrm{~ns}$ & $-0.91 \mathrm{~ns}$ & $-0.36 \mathrm{~ns}$ & $0.51 \mathrm{~ns}$ & $0.18 \mathrm{~ns}$ & $0.19 \mathrm{~ns}$ \\
\hline $\mathrm{P} \times \mathrm{A}$ & $-0.19 \mathrm{~ns}$ & $-0.71 \mathrm{~ns}$ & $-0.98 *$ & $-0.22 \mathrm{~ns}$ & $0.10 \mathrm{~ns}$ & $0.49 \mathrm{~ns}$ \\
\hline $\mathrm{F} \times \mathrm{A}$ & $0.01 \mathrm{~ns}$ & $0.49 \mathrm{~ns}$ & $0.15 \mathrm{~ns}$ & $-0.82 \mathrm{~ns}$ & $-0.31 \mathrm{~ns}$ & $0.77 \mathrm{~ns}$ \\
\hline
\end{tabular}

ns $=$ not significant $*=$ significant at $1 \%$ probability level $(\mathrm{p}<0.01)$ 


\section{Conclusion}

In conclusion, the data indicate that although the transgenic event affects some routes, amino acid synthesis (Asparagine, Glutamine, Tyrosine, Methionine, Valine, Phenylalanine, Leucine, Lysine, Isoleucine) was not affected in nutritional terms (oil and protein) by glyphosate applications at the studied doses $720,960,720 / 720,960 / 720$ and 960/720/720 g.i ha ${ }^{-1}$.

\section{References}

[1] "Amino Acids - Tyrosine". www.biology.arizona.edu. Accessed on September 27, 2019.

[2] ARRUdA, S. C. C.; BARBOSA, H. S.; AZEVEDO, R. A.; ARRUDA, M. A. Z. Comparative studies focusing on transgenic through cp4EPSPS gene and non-transgenic soybean plants: An analysis of protein species and enzymes. Journal of Proteomics, v. 93, p. 107-116, 2013.

[3] BARbOSA, H. S.; ARRUdA, S. C. C.; AZEVEDO, R. A.; ARRUDA, M. A. Z. New insights on proteomics of transgenic soybean seeds: evaluation of differential expressions of enzymes and proteins. Anal Bioanal Chemistry, v. 402, p. 299-314, 2012.

[4] BIELESKI, R. L.; TURNER, N. A. Separation and estimation of amino acids in crude plant extracts by thin-layer electrophoresis and chromatography. Analytical Biochemistry, v. 17, p. 278-293, 1996.doi:10.106/000-2697(66)90206-5.

[5] BILL, Phillips Sports Supplement Review 3rd Issue, Copyright, Golden, 1997.

[6] BONATO, R. E; BERTAGNOLli, P. F.; LANGE, C. E.; RUBIN, S. A. L. R. Teor de óleo e de proteína em genótipos de soja desenvolvidos após 1990. Pesquisa Agropecuária Brasileira, v. 35, p. 2391-2398, 2000.

[7] Cavuoto P, Fenech MF (2012). "A review of methionine dependency and the role of methionine restriction in cancer growth control and life-span extension". Cancer Treatment Reviews. v. 38, p. 726-36. doi: 10.1016/j.ctrv.2012.01.004.

[8] Cellarier E, Durando X, Vasson MP, Farges MC, Demiden A, Maurizis JC, Madelmont JC, Chollet P (2003). "Methionine dependency and cancer treatment". Cancer Treatment Reviews. v. 29, p. 489-99. doi: 10.1016/S03057372(03)00118-X.

[9] Douglas Harper (2001). "Tyrosine". Online Etymology Dictionary. Retrieved 2008-04-20.

[10] Edmund Drechsel, who first isolated it from Lysine casein. aminoacidsguide.com. accessed on September 27, 2019.

[11] FEHR, W. E.; CAVINESS, C. E.; BURMOOD, D. T.; PENNINGTON, J. S. Stage of development descriptons for soybeans. Glycine max (L.) Merrill. Crop Science, v. 11, p. 929-31, 1971.

[12] FRANCO, D. A. S.; ALMEIDA, S. D. B.; CERDEIRA, A. L.; DUKE, S. O.; MORAES, R. M.; LACERDA, A. L. S.; MATALLO, M. B. Evaluation of Glyphosate Application on Transgenic Soybean and its Relationship with Shikimic Acid.
Planta Daninha, v. 30, p. 659-666, 2012. http://dx.doi.org/10.1590/S0100-83582012000300023

[13] Guedes RL, Prosdocimi F, Fernandes GR, Moura LK, Ribeiro HA, Ortega JM (December 2011). "Amino acids biosynthesis and nitrogen assimilation pathways: a great genomic deletion during eukaryotes evolution". BMC Genomics. 12 Suppl 4: S2. doi: 10.1186/1471-2164-12-S4-S2.

[14] GRYNSPAN, F.; CHERYAN, M. Phytate-calcium interactions with soybean protein. Journal of the American Oil Chemist's Society, v. 66, p. 93-97, 1989.

[15] INRA, Alimentation et vieillissement. http://www.alimh.inra.fr/Les-recherches/Alimentation-etvieillissement/leucine-vieillissement/(key)/1, accessed on September 27, 2019.

[16] JEZOVSEK, G. K. Uma nova proposta para o controle das ervas daninhas: o uso de plantas transgênicas. 1997. In: SIMPÓSIO SOBRE HERBICIDAS E PLANTAS DANINHAS, 1 Simpósio sobre herbicidas e plantas daninhas. Dourados: EMBRAPA-CPAO, 62-74.

[17] Kisumi M, Komatsubara S, Chibata I (July 1977). "Pathway for isoleucine formation form pyruvate by leucine biosynthetic enzymes in leucine-accumulating isoleucine revertants of Serratia marcescens". Journal of Biochemistry. 82 (1): 95103.

[18] LATTA, M.; ESKIN, M. A. Simple and rapid colorimetric method for phytate determination. Journal Agriculture Food Chemistry, v. 28, p. 1313-1315, 1980.

[19] «Lysine». aminoacidsguide.com. accessed on September 27, 2019.

[20] MARUR, C. J.; SODEK, L.; MAGALHÃES, A. C. N. Free amino acids in leaves of cotton plants under water deficit. Revista Brasileira Fisiologia Vegetal, v. 6, p. 103-108, 1994.

[21] MATAVELI, L. R. V.; POHL, P.; MOUNICOU, S.; ARRUDA, M. A. Z.; SZPUNAR, J. A. Comparative study of element concentrations and binding in transgenic and non-transgenic soybean seeds. Metallomics, v. 2, p. 781-832, 2010.

[22] "Nomenclature and Symbolism for Amino Acids and Peptides". IUPAC-IUB Joint Commission on Biochemical Nomenclature. 1983. Archived from the original on 9 October 2008. Retrieved 5 March 2018.

[23] Pappenheimer AM (1987). "A Biographical Memoir of John Howard Mueller" (PDF). Washington D. C.: National Academy of Sciences.

[24] "Tyrosine". The Columbia Electronic Encyclopedia, 6th ed. Infoplease.com - Columbia University Press. 2007. Retrieved 2008-04-20.

[25] VOET, Donald; VOET, Judith G. Bioquímica. 4. ed. Porto Alegre, Artmed, 2013.

[26] YEMM, E. W; COCKING, E. C. The determination of amino-acids with ninhydrin. Analyst, v. 80, p. 209-214, 1995.

[27] Yasuhiko Toride. «Lysine and other amino acids for feed: production and contribution to protein utilization in animal feeding - Yasuhiko Toride»..fao.org. Retrieved February 20, 2016. 